vol. 1, 2010

\title{
SUSTAINABLE DEVELOPMENT AND ICT IN SLOVENIAN PRIMARY AND SECONDARY SCHOOLS: MEDIA-ECOLOGICAL PERSPECTIVE
}

\author{
Srečko Zakrajšek and Peter Purg \\ Institute and Academy of Multimedia, Slovenia
}

\begin{abstract}
The goal of the research was to get an overview on the possibilities of sustainable development in relation to information and communication technologies in primary and secondary schools in Slovenia from the perspective of media ecology. The study analyses the reasons for a reorientation of the educational system and new programmes towards sustainability and relates these developments to the activities of Eco-schools in Slovenia. The findings show that the guidelines of sustainable development are included in the programmes, yet they do not encompass the possibilities opening up by new technologies. Contemporary teaching methods are not widespread due to the inadequate education and training of teachers. At the same time, numerous problems arising from the introduction of new technologies and equipment into schools are neither anticipated nor tackled in the renewed curricula, thus failing to integrate a contemporary media-ecological perspective. Judging from the roadmap documents, even after the renewal process will have been finished, the situation will hardly change unless major changes are introduced into the planned concept of renovation and additional investments of funds for equipment, the preparation of materials and, above all, teacher education are secured.
\end{abstract}

Key words: information and communication technologies, primary and secondary education, Eco-schools, sustainable development, media-ecological perspective

\section{Introduction}

The goal of this article is to define the opportunities that information and communication technologies (ICT) present in the field of teaching under consideration of the principles of sustainable development in the educational system. It also seeks to establish how these elements are included in developmental and operational programmes of the Slovene primary and secondary educational system and to what extent the school management is familiar with them. The study also poses the question whether the new programmes and especially the everyday school practice takes into account the problems that arise from the introduction new technologies and equipment. New forms and possibilities of education stimulate the adaptation of schools in terms of programmes, as well as concrete transactions: building new work spaces, buying and maintaining equipment, consumption of energy, waste management, equipment recycling, etc.

In the programming documents of the Slovene educational system, environmental education is specified as a special subject with the purpose to educate on sustainable development. The programme is designed in accordance with the recent principles of UNECE (United Nations Economic Commission for Europe), which declared the period of 2005-2014 as a decade of education for sustainable development (UNESCO, 2006). The 
Slovene programme for primary schools was accepted in 2009 (National Education Institute of Slovenia, 2009b) and for the renovated secondary schools as early as in 2008 (National Education Institute of Slovenia, 2008b).

In this article the first research phase covers an analysis of the previously mentioned accepted documents and other secondary data collected, whereas the second phase investigates the real situation in the field with the help of a survey conducted among principals of Slovenian primary and secondary schools. The results are compared to their equivalents in the field of education in more developed EU countries. The study also draws on the phenomenon of Eco-schools which in Slovenia represent a vital and successful part of the environmental education along the guidelines of education for sustainable development (ESD). In the course of the argumentation, several critical issues concerning media ecology and sustainability are raised accordingly.

\section{Demands and possibilities of sustainable development in Slovenian school programmes}

On the highest level of civil organisation, along the lines of the United Nations' activities (for instance, OECD, 2000; WSIS, 2005), the European Union (EC, 2009) defines and seeks to mainstream sustainable development as a high priority for cultural, social and economic development, which especially in the recent years has strongly affected the realm of education. Thus the need to equip young people with the necessary key competences and to improve educational attainment is an essential part of the European Union's strategy for sustainable growth, progress and development in general, as it underlines the objectives set out in the Member States' National Reform Programmes. The demand for competence is two-fold here: rapid technological progress requires high and constantly updated skills, while growing internationalisation and new forms of company organisation, call for a social, communicative, entrepreneurial and cultural competence that helps people adapt to the changing environments (EC, 2007).

Improved educational achievement is important for individuals, because people's achievement in compulsory school has a strong direct impact on their later educational achievement and social status (Rice, 1999). It is also important for society at large, given that increased achievement (as measured by average performance on comparable international students' tests, such as PISA and TIMSS) is strongly linked to economic growth (Maani, 2007). A rise in the overall level of achievement of European high school students is thus expected to improve the Union's competitiveness and economic growth, as well as raise the population's awareness of and sensitivity towards the issues and challenges of sustainable development, notwithstanding its social and ecological dimensions.

We have to be aware of the fact that without equipment, infrastructure, quality materials, as well as educated and qualified teachers, the future of the school looks uncertain - teachers should learn to use ICT-based teaching methods (Praprotnik \& Zakrajšek, 2008). The digital divide in terms of equipment, as well as know-how and knowledge is a fact with which many of the less developed EU countries have been facing ever since; so have all the EU accession candidates (Gulati, 2008).

The use of ICT is essential and may be the only possible way to achieve certain goals which have been established by both theoreticians and practitioners. To mention just a few of these areas:

- $\quad$ effective learning and accessibility of information; 
- (inter)subject cooperation;

- interactive global communication;

- reduced and simplified administration;

- e-materials, learning by distance;

- transparent preparation and realisation of the educational process;

- simple and effective checking and grading of knowledge;

- the possibility of sustained communication - students, teachers, parents;

- effective cooperation of teachers at home and abroad;

- accessibility of quality materials and lectures to all students.

Last but not least, with less travelling, less time, energy and space spent or wasted because of partial (blended) e-education by distance, more equal opportunities open up through virtual access or the combination of virtual and concrete human interactions, by experiencing different places and cultures without the hazardous effects on environment and with the new possibilities of global communication, learning and using foreign languages. This exemplifies the crucial role of media and ICT in implementing the vision and mission aimed at sustainable development. With sensible use of ICT, the consumption of resources can be drastically lowered (paper, colour chemicals, fuels, etc.), as well as the use of energy diminished "smart schools", e-optimized transport. A very important opportunity that modern technologies offer is to spend less time on unnecessary activities, such as transport or organisation, which assures more free time for (extracurricular) activities that have a positive effect on physical, cultural and social life quality.

\section{The dilemmas and problems of ICT in education}

The first scientific articles on dilemmas about the new, electronic ICT in education appeared in the early nineties. In his famous book, Virtual Community, Rheingold (1993) exposed the social and communicative qualities of the internet that also pertain to learning, whereas Burnett and Marshall (2003) wrote about to possibilities for groups and communities to form knowledge outside traditional space and time limits. However, the authors also criticised "technological rationality" that forced ICT and especially the Internet with its manifold possibilities to be quickly implemented and integrated into as many fields of everyday life as possible. In the last two decades, the use of the Internet became a major social trend, thus the question of what content or structure would be wise to establish online and in which areas we could use it to maximise social and economic sustainability, is becoming more and more important.

By equipping schools with ICT, with the globalisation and manifold social spreading of the Internet, accessibility to unconfirmed or unedited information, possibilities of misuse and new forms of criminality arise. Especially with the introduction of new working methods, completely new economic and social problems occur, for which solutions are sought especially in the form of different restrictions, anti-criminal sanctions, the locking down of certain websites, censoring contents, etc. On the other hand, ICT equipment is becoming a major investment and maintenance cost for schools, it uses up to $10 \%$ of electric energy and produces $2 \%$ of carbon dioxide (EC, 2008). Every three to four years, the computer equipment needs to be changed thus incurring high system maintenance costs. In recent years, marked by many dilemmas about ICT in education, the EU accepted a series of documents where ICT-supported education and schooling of young Europeans 
was presented as a key competence for a successful life and society: interactive use of resources, the ability of enriching knowledge and fast or complex exchange of information.

Furthermore, in the search for relevant information to illustrate environmental peculiarities, critical analysis of media technologies and messages can play a vital role (for students and teachers alike) by investigating the sensible use of media technologies (radio, television, World Wide Web, newspapers, popular and scientific writings, video, etc.). Young people increasingly accept different (new) media spaces as normal (default) environments of communication and social exchange (Purg, 2008, WSIS 2005, art. 90n), and these fast developments call for a well-guided and profoundly organised reflexion and critical approach towards media ecology as such (Purg, 2006). The concept of media ecology here is referred to firstly in its most traditional understanding in terms of a discipline defined by Postman (1970) as looking into the matter of how the media of communication affect human perception, understanding, feeling, value and how interaction with media facilitates or impedes our chances of survival. Secondly, Nystrom (1973) expected media ecology to study complex communication systems as environments, focusing interest upon interactions of communications media, technology, technique and processes with human feeling, thought, value and behaviour. Whereas Sandbothe (2004) understands the position of media ecology dynamically as one of counterbalance forces, reestablishing the "neglected" media: for educational contexts in the nineties this was beyond doubt ICT - the personal computer and the internet, but nowadays new (and converging) social and mobile media are arguably the ones critically underrepresented in everyday school realities.

\section{The research approach}

In the frame of the research, an analysis of the most important documents in the field of sustainable development and ICT in Slovene schools was carried out. Two pieces of research were performed by surveying primary and secondary school principals in order to obtain original data. We compared the results of our research with secondary sources and especially with the UN and EU guidelines and data on the most developed countries in the EU. As basic secondary data material for the research, the official documents were selected, including: Environmental education curriculum as education for sustainable development for primary (National Education Institute of Slovenia, 2009a) and secondary schools (National Education Institute of Slovenia, 2008a), Teaching plan for the optional subject Environmental education for primary (National Education Institute of Slovenia, 2009b) and secondary schools (National Education Institute of Slovenia, 2008b), the Position Paper on Renovation of the High School Program (The Council of Experts, 2007) and the Analysis of the national Pedagogical institute (Grmek 2006). ICT equipment and usage of modern methods of education data were four years old, but still quite reliable and, above all, thorough (Gerlič, 2005). Comparative information about the equipment of schools in Slovenia and the EU was obtained from the Ministry of Education and Sports (Colnar, 2008). Eventually, reference to two original researches is made: Research of the opinions of primary school and high school principals concerning ICT and sustainable development and the research of conditions in the field of ICT in Slovene secondary schools (Zakrajšek, 2009). 


\section{Analysis of position papers and programmes of environmental education in Slovenia for primary and secondary schools}

In the general environmental education curriculum formulated as "Education for Sustainable Development for Primary Schools" (National Education Institute of Slovenia, 2009a) and "Education for Sustainable Development for High Schools" (National Education Institute of Slovenia, 2008a), three basic dimensions seem to be increasingly interconnected in the programmes: education on environment (general ecology); education in the environment to encourage research and investigation (interactive and investigative approach); education for the environment stressing the importance of seeking and establishing sustainable, co-natural solutions (proactive and productive approach).

In this field, ICT has a very important role because it facilitates international contacts, collaborative projects and direct comparisons, publicity and dissemination, as well as gaining access to up-to-date information and co-producing knowledge. Yet, in a more detailed review of programmes, we could establish that they are oriented in a rather traditional way and that they hardly encompass the possibilities that have arisen from the recent global developments in environmental issues, especially in new technologies that call for essentially different approaches. Interestingly, there is practically no orientation towards changing the habits in sustainable consumerism especially in the (continuously rising) field of ICT hardware and software, as well as media content or messaging.

The programme should be realised, according to the documents at disposal:

- in individual self-educational subjects;

- in the frame of the mandatory optional subject "Environmental Education";

- in the frame of days of activities, schools' project weeks and projects;

- $\quad$ in the frame of supplementary activities or as partial interest activities;

- $\quad$ as a part of a departmental community or guidance programme;

- with joining pupils in social activities and in innovation-development projects.

Didactic methods with which the goals of the environmental education would be fulfilled are:

- $\quad$ direct experience in a natural environment;

- analysis of everyday life experience and habits from the point of view of environmental influence;

- $\quad$ students' group work (working in groups enables, apart from active gaining of new knowledge, also social learning);

- incorporating dialogic or interactive lessons;

- $\quad$ project work;

- role play and simulations;

- didactic games;

- environmentally important actions.

We here claim that all the above points (except perhaps for the first one) could be facilitated, accelerated, diversified and, above all, made more attractive and contemporary in both form and topical focus exactly through careful implementation of ICT. Especially in terms of facilitating long-distance multimedia-supported and asynchronous communication this is quite obvious. And even more so, if taken into account that for the realisation of the goals of the environmental education as an education for sustainable development the 
documents agree it is important to connect the school with local (through practical experiential environmental activities) and wider environment, connect schools among each other (also in an international aspect) and make them cooperate with external experts.

Even if basic in scope and depth, the propositions for including ICT in the modern class exist outside the ESD programmes, yet a lack of familiarity in the practical and theoretical field can be noted in the realm on the entire national level. The largely unexploited possibilities they provide (Purg, 2006) and the influence that multimedia and ICT already have shown over modern education should in the future hold a much more important, if not the key role in the systemic approach of renewing educational concepts and programmes.

"The Position Paper on Renovation of the High School Program" (2007) starts with an analysis of the state of the art that shows a clear need for change and demands for new and increased capabilities for successful facing with these changes (mostly described in terms of a "challenge"). Among the 13 goals, the ones that clearly relate to the use of ICT and sustainable development, could be the following: to achieve a high quality and diversity of knowledge among students (nowadays hardly possible without the support of ICT); to develop responsibility and ethical treatment of self, natural and social environments among students, to qualify students for constructive solving of life's problems and situations (i.e. many pertaining to the manifold and new media-scapes), to develop their different levels of literacy, including media literacy, raise them to the level of excellence and to develop their ability for independent, critical thinking and judgement (for instance, within the many data sources available just-for-the-cause and just-in-time).

Protection of all aspects of the natural environment is mentioned as a condition of sustainable development as a development of responsibility in relation to the natural environment - yet the social or psychological or even technological (i.e. media) environment is not mentioned. The realisation of the schedule is directed mostly into achieving content goals, while the principle of goal-oriented learning and development process is not used enough; an insufficient amount of time and space is dedicated to acquiring and processing information and content, as well as to present and analyse the results of these processes.

On this basis, we have furthermore taken into account a "Comparison of the state in the field of ICT in EU" (Colnar, 2008) and have previously conducted a similar own and original analysis for Slovene secondary schools (Zakrajšek, 2009). In EU25, for every 100 students in secondary schools in the year 2006 they had 12.5 computers available, but in EU15 - 15.6. In Norway, this figure was as high as 41, in Sweden - 29, in England - 26, in Finland - 18 and in Slovenia - only 8. According to the information in a poll among highschool principals (Zakrajšek, 2009), in January 2009, Slovene secondary schools still had between 8 and 19 computers per 100 students, alarmingly showing that within the three years (mostly a time of steep economic growth) between the two researches this equipment lag has hardly improved. According to Colnar (2008), the percent of teachers using a computer for conducting a lesson in 2006 was alarming as well. The EU25 average in secondary schools was $73 \%$, in the EU15 76.1\%. In Slovenia a computer was used by $54 \%$ of teachers - a bottom performance at 22nd place. According to the information from our primary research (Zakrajšek, 2009), three years later the computer was used for lessons by approximately $60 \%$ of the teachers in high school, while the use of e-platforms or learning management systems for teaching (mostly Moodle) is still in the beginning, being used in less than a third of all schools.

An underestimation of the possibilities that ICT offers for implementing a high school programme and neglecting the insufficient qualifications of teachers for successful 
work with ICT is obviously quite common for this kind of national analyses that usually discuss problems of space and the number of students in groups as the only resource-bound parameters. In order to achieve the aforementioned goals, the most successful methods at hand (all obviously supportable by ICT) are interconnecting subjects, multidisciplinary approaches in relation with interactive correspondence, real-time checking, grading and feedback on the acquired knowledge, etc. On the most part, all this can be importantly enabled or enhanced by interactive and/or multimedia e-materials, social-media based internet portals, various ICT-based games, simulation programmes through different media, etc. Of course, these should be considered partly as additions and mostly as complementary methods and should not be mistaken as guarantees for successful education processes - the immediate local and physical presence will always play a pivotal role, especially in primary and secondary education stages.

\section{Analysis of ICT elements in connection with sustainable development in Slovenian Eco-schools}

Eco-schools is a programme of an international association for environmental education (Foundation for Environmental Education, FEE), that is active in schools and kindergartens in 58 countries across the globe. In Slovenia, the programme was named Eco-school as a way of life, the operator of the programme being the Slovene Foundation of Environmental Education in Europe. In 2008 and 2009, there were 548 institutions enrolled in the programme nation-wide, (primary and secondary schools, kindergartens and CSOAs, Centres for School and Outdoor Activities), which is certainly a lot for a nation of only 2 million people (with around 850 primary schools and 800 kindergartens in total for the nation). The programme in Slovenia introduces an intentional and holistic environmental education in primary and secondary schools in accordance with the 7-step methodology related to the ISO standard 14001. Environmental education is included as an integral part of the goals and contents of each individual subject or curriculum element. It includes natural science activities for connecting goals and contents among subjects, goals of value in the life of a school, guiding reflections of creativity over new ideas and (re)organising educational work within the school in relation to the locality and decision makers. It also importantly connects young people with their peers from the countries in the rest of Europe and the world.

In 2009 and 2010, numerous projects were taking place in the Slovene Ecoschools.

- Animals and us.

- Poverty at home and in the world.

- We and our past for a permanent future.

- Where are climate changes leading us?

- Karst - opportunity for teachers and pupils.

- Watching and protecting biodiversity.

- Early natural science.

- Healthy way of life.

- Water as life's value.

- Waste.

- $\quad$ Effective use of energy in the school. 
- $00 \mathrm{CO} 2$, Agents of low carbon society in action.

- Traffic pollution and sustainable mobility.

Two of the projects explicitly deal with ICT elements and sustainable development, whereas most others presumably also include ICT for communication, documentation and, above all, dissemination goals, but do not treat it topically.

The subject or project within an Eco-school member is usually chosen according to the level of importance for the respective school, in the town or the surroundings. In the programme of Eco-schools sustainable development and sustainable consumption are interestingly not explicitly mentioned. This is probably because the schools were founded in the year 1994, when these paradigms did not exist as such in the prevailing discourse, neither was there education for teachers on sustainable education, nor a dedicated programme for educating teachers. Along with the above considerations on ICT, these elements and recommendations or demands should be entered into the programme of Ecoschools and thus upgraded. In fact, an individual school can enrich its yearly activity programme with various activities from the field of ICT and sustainable development - and some indeed do this directly, for instance, saving energy within use of ICT (mainly computers and other multimedia hardware), safe removal of used ICT equipment, the use of ICT for doing business and education, showing that these goals can also be achieved indirectly, as ICT is becoming an integral part of the school's life, affecting its entire field of practice and programming.

Eco-schools represent a vital part of the education for a sustainable development in the Slovene educational system because they include general and specific concepts and concrete examples of topical actions in schools and their immediate and remote environment. With a systematic introduction of elements of sustainable development which are based also on ICT, some schools have managed already to implement these processes on a relatively large scale. With the help of suitable programmes on national level, especially through educating teachers, the incorporation of an integrated model of ESD and ICT could be viable in the majority of Slovene schools.

\section{The importance of ICT for sustainable development in primary and secondary education in Slovenia}

In the period from January until December 2009, research was undertaken in Slovene primary and secondary schools on the connection of information and communication technologies with the concepts and practices of sustainable development in education (Zakrajšek, 2009). The research was done via an online survey among 127 proportionally chosen schools, which means that the schools that answered already use ICT. That is why it needs to be kept in mind that the results obtained are significantly better than if we were to check the opinions of all principals and situations in all schools across Slovenia.

The survey encompassed 33 questions of which there were 9 binary YES/NO questions, 3 questions that demanded data input, 2 multiple-choice questions with three answer options and 17 questions with the level of acceptance; twice the participants had a chance to state their opinions in short essay form. The results below represent a combination of all data acquired. The survey consisted $82 \%$ of primary schools and $18 \%$ of secondary schools, which in total represent about $15 \%$ of all the primary schools and around $10 \%$ of all secondary schools in Slovenia. $45 \%$ of the surveyed schools were part of the Eco-schools network. 
The schools surveyed have an average of $58 \%$ of classrooms equipped with a computer and a data projector. The schools have 16 computers per 100 pupils on average. $8.8 \%$ of schools' buildings were built according to energy-saving principles and only a couple of them claim to have integrated some kind of a (centrally operated) intelligent or smart house management system. Nonetheless, $35.3 \%$ of the principals are planning to bring their schools up to modern standards in terms of ecological sustainability in the near future. In $41.2 \%$ of the polled schools, classes are being held with the help of an e-platform - mostly Moodle. In the majority of the schools, this platform is being used by $10 \%$ to $20 \%$ of the teachers, which is definitely a worrying figure, as these platforms prove efficient only if their use is widespread and well integrated at the school level (Mastnak et al, 2009). Interestingly, only $38.2 \%$ of the principals think that the teachers are more burdened by the new technologies. Principals estimate that $64.2 \%$ of the pupils are familiar with the principles of sustainable development and sustainable consumerism. $91.1 \%$ of schools switch off the computers when they are not being used. Principals have subjectively graded how well their schools are equipped with ICT: $5.9 \%$ - very bad, $70.6 \%$ - good and 23.5\% excellent.

Results that can be considered positive for using ICT in schools, as related to ESD:

- $79 \%$ of the principals agree that accessibility to information and environmental projects via internet speeds up knowledge transfer and successful solutions in a certain environment.

- $76.5 \%$ of the principals agree that cooperation of the parents via e-mail can drastically decrease the time and fuel spent in comparison to traditional ways of communicating with parents.

- $72.6 \%$ of the principals agree that with the help of modern technologies we can reduce the use of energy, consumption of materials and decrease the pollution of the environment.

- $67.7 \%$ of the principals agree that accessibility to material on the internet increases the accessibility of education in general.

Results that can be considered as negative for using ICT in schools, as related to ESD:

- Only $20.8 \%$ of the principals agree that the use of ICT in education improves the relationship between the teacher and the student, but nobody strongly agrees with that statement

- Only $29.4 \%$ of the principals agree that young people are well equipped for using modern technologies, so they could perform distance education in large numbers, but nobody strongly agrees with that.

Measures to be implemented gradually: It is vital to inform, to raise awareness and to educate principals and teachers for constructive and ESD-compatible use of new technologies with the help of good practice examples, as well as with structured curricula and systematic improvements, including investments.

Results that can be considered as negative for implementing the guidelines of ESD in schools:

- Only $11.8 \%$ of the principals do not agree with the score showing that the elements of sustainable development are not sufficiently encompassed in the 
programme and the goals of the school, most of them (58.8\%) are of the opinion that this is true or they are indecisive $(29.4 \%)$

- $56 \%$ of the principals admit that they do not master enough (new) teaching methods to be able to prepare a high-quality implementation programme related to education for sustainable development; only $14.7 \%$ think that this is not true or claim that they know enough

- Only $47.7 \%$ of the principals think that there exist enough programmes for educating teachers on implementing elements of sustainable development in schools.

Urgent measures to be taken. Appropriate programmes need to be prepared or renewed for introducing teaching (especially revising teaching methods) according to the concepts of sustainable development, it is also urgent to familiarise principals with the concepts and (good) practices of ESD, as well as systematically educating and qualifying the teachers.

When asked about why they think that introducing modern technologies in schools is slow and difficult, $70.6 \%$ of the principals agreed that there are plenty solutions available, but mostly lamented that they need to be continuously renewed and the market is fast-growing, thus it is hard to follow it in terms of equipment and user knowledge. $46.8 \%$ of the principals agreed that there are no suitably created applications and no relevant instructions available for pedagogical use, $58.8 \%$ of the principals agree that the teachers are not qualified enough to use the existing technologies correctly and efficiently. Nevertheless, an important reason (gathered from open questions) seems to also be massive financial costs that the new technology brings not only in terms of investment, but also in terms of maintenance. Yet, it is still highly important that most $(73.6 \%)$ principals are well aware that young people want such technologies - and would expect schools to be equipped with them and teachers to know how to use them in class.

\section{Discussion and conclusions}

The Slovene educational system has abided by the recommendations of UNECE, where the period 2005-2014 was declared a decade of education for sustainable development (UNESCO 2006). The basic starting point of the Slovene national programme is to place environmental education concerning goals, as well as contents, methods and principles used into all subjects and fields within subjects of primary and secondary school curricula. This is, however, problematic, already if taking into account experience gained from previous experience in other countries, as individual fields have their own specific approaches and demands often resistible to change. That is why it proves sensible to implement elements of sustainable development transversally into all school activities as a component part and in some selected projects specify the necessary actions for successful implementation of the elements of sustainable development, for instance, activities that belong to the framework of Eco-schools and even transversal ICT- or media-(ecology-) related activities, where the media-scape is understood as environment in terms of the traditional ecological metaphor, transposed into the new-media reality.

Our research has shown that principals are mostly familiar with the benefits and in some fields even actively supportive of the use of ICT in schools (for instance, accessibility to information and materials, contacts with parents, decrease of energy and material use), yet that they largely do not understand these developments within the conceptual framework of ESD. They, however, mostly realise that young people want technology in 
schools not only for fun or hype, but rather for its practical (education bound) usability and sometimes even for ecological use. Understandably, principals are more reserved when it comes to fields that directly intersect with pedagogical work (for instance, partial distance or blended education forms, relations between pupils and teachers, or teachers and parents). There are many reasons for the above defined lags, but the main ones are obviously unsatisfying and belated programmes, missing usage instructions and guidelines for pedagogical use, lack of educated teachers and not least the massive financial costs connected with new technologies. Beyond this, the principals also stated that there is a problem with sustaining the activities of ESD over longer periods of time, which obviously corresponds to the problems in other similar countries (for instance, Estonia as described by Lukk, Veisson, \& Ots, 2008).

For the greater part, the principals admit that they are not familiar enough with the programme of sustainable development, not being involved in the programming and the setting of (external) goals of the school's attainment, they also stress that there is not enough suitable training available for the teachers in the field of ESD. Moreover, for a successful introduction of ICT in accordance with the premises of sustainable development into the Slovene educational system, a lot of additional knowledge, energy and funds will be needed. The previously prepared starting points will need to be revised in certain segments, and the programmes will need to be constantly updated and their implementation determined more precisely. Providing information systematically, raising awareness, educating and training principals and, above all, teachers and ensuring sufficient funds will be needed to sustain a modern educational system.

Programmes should be implemented with modernised concepts more related to the realistic life of every individual in the world permeated by new media forms and contents, instead of recycling traditional concepts of ecology that condemn technology (as opposed to nature or humanism) in principle and with it the beneficial aspects of ICT. Modern trends are orientated towards receiving energy directly from solar sources (be it on vehicles, buildings or mobile appliances) and towards a sustainable consumerism, where the role of the individual is greater and more immediate than in the mass consumerism paradigm (EC, 2009). The same goes for obtaining information directly from the source in the networked paradigm of new media! With every developed procedure all of the direct and the indirect influences on the environment should be defined - on the political and especially on the legal level - to prevent environmentally unfriendly solutions and technologies. In schools, pupils should be involved in the entire scope of processes from planning to execution in order to get familiar with benefits and problems of individual activities concerning the use of natural resources and energy, as well as impacts on the environment. Additionally, the usage periods of equipment will need to be prolonged, assuring upgrades instead of replacements.

Schools should, above all, give bright local examples for power saving in buildings, solving waste problems, rational usage of material, designing healthy diets, arranging and optimising ICT systems and, of course, educating teachers (as primary adults disseminating knowledge) towards all these goals. Practical solutions in the field of sustainable development and consumerism that the schools resolve to should be on the highest level because in such a way they would transfer and mainstream this knowledge via young people into the families. Yet, in most fields this is sadly not the case, and, because of the financial constraints, the education system can only resolve to gradual steps, often leading to stagnation. There is a big problem also in the national union of schools and its normative organisation - dividing education into subjects of traditional form arranged throughout the school year, non-flexible working hours (most teachers in Slovenia work 
until 3 PM), low system flexibility, not enough autonomy of the schools within the national union of schools, etc.

The research and study covered by the article have thus shown that Slovene primary and secondary schools are falling behind the developed countries of the EU in the area of ICT equipment and emancipated usage - as equipment capacity should only be the basis for the confident use of ICT with the aim of lifelong learning, even in distance education settings (WSIS, 2005, art. 90c). Besides equipment problems, there is also a severe lack of qualified staff and quality learning materials and, above all, a complete absence of holistic concepts and methods. Sustainable development is incorporated within only a few subjects (chemistry, biology, geography) and predominantly in relation to traditional ecology. It thus completely fails to respond to the contemporary concepts of media ecology (Purg 2006 and 2008) or at least to involve an understanding of the social context of science and technology by adequate teacher training, as pointed out by Jonane (2008). There is a comparatively large number of projects in progress on the subject of protecting the environment in the framework of Eco-schools that include more than half of all Slovene schools, yet a contemporary, ICT-emancipated focus is somewhat missing. In the school year 2009/2010, two projects are being implemented where the reduction of energy in the use of ICT equipment is mentioned explicitly, which could be a sign of improvement of this aspect.

Even after the renovation of primary and secondary schools (according to the planned documents) the situation is not likely to change, unless major shifts are made in the planned concept of renovation and additional investments of funds into equipment, preparation of materials and, above all, teacher education are implemented. With a sustainable implementation of ICT, it is possible drastically to improve school programmes and ensure that everyone remains focused on their technical tasks as much as possible and, at the same time, actively engage in social interaction and knowledge transfer. Pupils and students deserve the modern methodologies and equipment, especially in the light of their talents, as in this way they will more likely gain a competitive position in studies and work and be able fully to realise their potentials - this in accordance with goal 8 of the Millennium Development Goals of the OECD to improve youth learning skills and employability in order to meet the challenges of the knowledge-based global economy of the 21 st century (OECD, 2000). With modern organisation and delivery of lessons, it is also possible more easily and adequately to achieve informational, educational and schooling goals along the principles of ESD and give the youth proper skills, habits and values with which they will engage in sustainable living practice and secure it for the coming generations. If carefully implemented in the contemporary concepts of sustainable development by observing the guidelines of (new) media ecology, ICT can enable a lowering of the unnecessary burdens on people and environment and guarantee a more optimal use of resources, as well as a better life and equal opportunities for all humankind. The aforementioned European guidelines commit us to ensuring a quality education for all youth and to qualify and motivate them for life-long learning and acting according to the principles of sustainable development, and, without a doubt, ICT can play an important role in living up to these commitments.

\section{References:}

Burnett, R., \& Marshall, D. P. (2003). Web theory. An introduction. New York: Routledge. Colnar, M. (2008). Indicators of ICT development. Ljublana: Ministry of Education and Sports. 
European Commission, EC. (2007). Schools for the 21st century. Commission staff working paper, Commission of the European Communities, Brussels, SEC (2007) 1009. Retrieved December 20, 2009, from http://ec.europa.eu/education/school21 /consultdoc_en.pdf.

European Commission, EC. (2009). Mainstreaming sustainable development into EU policies: 2009 review of the European Union strategy for sustainable development. COM (2009) 400. Retrieved September 21, 2009, from http://ec.europa.eu/sustainable/ welcome/idea_en.htm.

European Commission, EC. (2008). Communication from the Commission to the European Parliament, the Council, the European Economic and Social Committee and the Committee of the Regions. Addressing the challenge of energy efficiency through information and communication technologies. Commission of the European Communities, Brussels, COM (2008) 241. Retrieved December 10, 2009, from http://ec.europa.eu/information_ society/activities/sustainable_growth/docs/com_2008_241_1_en.pdf.

Gerlič, I. (2005). Didactic questions of information and communication technologies in Slovene secondary schools. Maribor: University of Maribor, Faculty of Education.

Grmek, M. I. (2006). Evaluation of secondary schools from the aspects of extensive teaching plans, connective knowledge and goal representation. Ljubljana: Pedagogical institute.

Gulati, S. (2008). Technology-enhanced learning in developing nations: A review. International Review of Research in Open and Distance Learning, 9(1). Retrieved August 21, 2009, from http://www.irrodl.org/index.php/irrodl/article/view/477/1012.

Jonane, L. (2008). The didactical aspects of integrated natural science content model for secondary school education. Journal of Teacher Education for Sustainability, (9)1, 45-57.

Lukk K., Veisson, M., \& Ots, L. (2008). Characteristic of sustainable changes for schools. Journal of Teacher Education for Sustainability, (9)1, 35-44.

Maani, K. (2007). Childhood economic resources, academic performance, and the choice to leave school at age sixteen. Economics of Education Review, 26(3), 361-374.

Mastnak, T., Purg, P., \& Budihna, A. (2009). Gradual holistic introduction of e-learning in a general gymnasium high school. In Proceedings of the 12th international multiconference information society - IS 2009, 16 October 2009 (pp. 52-53). Ljubljana, Slovenia: Kranj, Faculty of organization sciences.

National Education Institute of Slovenia. (2009a). Curriculum: Environmental education as ESD, for primary schools. Ljubljana: The National Education Institute of Slovenia.

National Education Institute of Slovenia. (2008a). Curriculum: Environmental education as ESD, for high schools. Ljubljana: The National Education Institute of Slovenia.

National Education Institute of Slovenia. (2009b). Lesson plan: Optional subject environmental education for primary schools. Ljubljana: The National Education Institute of Slovenia.

National Education Institute of Slovenia. (2008b). Lesson plan: Optional subject environmental education for high schools. Ljubljana: The National Education Institute of Slovenia. 
Nystrom, C. (1973). Towards a science of media ecology: The formulation of integrated conceptual paradigms for the study of human communication systems. Unpublished doctoral dissertation, New York University, New York.

Organisation for Economic Cooperation and Development, OECD. (2000). Millennium declaration at the General Assembly. How ICTs can help achieve the millennium development goals. Retrieved August 21, 2009, from http://www1.oecd.org/dac/ ictcd/docs/otherdocs/ Forum_0303_roomdoc6.pdf.

Praprotnik, T., \& Zakrajšek, S. (2008). Multimedia in education and everyday life. The Journal for the Criticism of Science, (36)233, 216-230.

Postman, N. (1970). The reformed English curriculum. In A. C. Eurich (Ed.), High school 1980: The shape of the future in American secondary education (pp. 160-168). New York.

Purg, P. (2006). An ecological approach to multimedia in teaching and training: Advancing business and management in knowledge-based society. In Proceedings of the 7th international conference of the Faculty of Management Koper, University of Primorska, [tudi MIC'06] 23-25 November 2006. Portorož, Slovenia: Koper, Faculty of Management, 1509-1514.

Purg, P. (2008). Ecology of web 2.0. (Presented at the conference) Dnevi slovenske informatike 2008 - DSI, Portorož, Slovenija, 9-11 April. Interoperabilnost kot izziv informatiki, Zbornik prispevkov. Ljubljana: Slovensko društvo Informatika.

Rheingold, H. (1993). The virtual community. Homesteading on the electronic frontier. New York: William Patrick Book, Harper Collins.

Rice, P. (1999). The impact of local labour markets on investment in further education. Journal of Population Economics, (12)2, 287-312.

Sandbothe, M. (2004). Statement zur aktuellen Debatte über Mediologie, Medienökologie und Medienphilosophie. Retrieved August 21, 2009, from http://www.sandbothe. net/359.html.

The Council of Experts. (2007). Position paper on renovation of the high school program. Accepted on 101th Meeting of the Council of Experts on General Education of the Republic of Slovenia, 19. 04. 2007.

UNESCO. (2006). UN Decade of Education for Sustainable Development (2005-2014). Retrieved August 21, 2009, from http://portal.unesco.org/education/en/ev.php.

World Summit on the Information Society, WSIS. (2005). Tunis agenda for the information society. Retrieved August 21, 2009, from http://www.itu.int/wsis/docs2/tunis/off/ 6rev1.pdf.

Zakrajšek, S. (2009). Information and communication technologies in Slovene secondary schools: A research. Ljubljana: Institute and Academy for Multimedia.

\section{Correspondence:}

Dr Srečko Zakrajšek, Institute and Academy of Multimedia, Leskoškova 12, 1000, Ljubljana, Slovenia. Tel: +386 40702 195; Fax: +386 15240155 .

Email: sreco.zakrajsek@iam.si 